\title{
New Directions for Entrepreneurship through a Gender and Disability Lens
}

\author{
Dr Jannine Williams \\ jannine.williams@qut.edu.au \\ QUT \\ Gardens Point, Z Block Level 9912 \\ Brisbane, Australia \\ 4000 \\ Tel: +61731381298 \\ *Dr Nicola Patterson \\ nicola.patterson1@ @ewcastle.ac.uk \\ Newcastle University Business School, \\ Newcastle University, \\ 5 Barrack Road \\ Newcastle upon Tyne. \\ NE1 4SE, UK \\ Tel: +44 (0)191 2082325
}

*Corresponding author

\begin{abstract}
Purpose

There is a dearth of studies exploring the intersection of gender and disability within entrepreneurship research. This is despite women's entrepreneurship research encouraging an expansion of the research questions asked and approaches taken. As a contribution to this debate this paper develops an understanding of gender and disability as social categorizations which can shape entrepreneurial opportunities and experiences for disabled women entrepreneurs.
\end{abstract}

\section{Design/methodology/approach}

The paper offers an intersectional conceptual lens for the study of disabled women entrepreneurs to explore a concern for a particular social group - women - at a neglected point of intersection disability - within the social setting of entrepreneurship. Guided by the research question how can 
gender and feminist disability theory contribute to the development of an intersectional theoretical lens for future entrepreneurship research?, the potential for new theoretical insights to emerge in the entrepreneurship field is identified.

\section{Findings}

Through a gender and disability intersectional lens for entrepreneurship research four theoretical synergies between gender and disability research are identified: the economic rationale; flexibility, individualism and meritocracy; and social and human capital. In addition to the theoretical synergies the paper highlights three theoretical variances: the anomalous body and bodily variation; sexuality, beauty and appearance; and multiple experiences of care as potentially generative areas for women's entrepreneurship research. The paper identifies new directions for future gender, disability and entrepreneurship research by outlining research questions for each synergy and variance which draw attention to disabled women entrepreneurs' experiences of choice and control within and across different spaces and processes of entrepreneuring.

\section{Originality}

The conceptual intersectional lens offered to study disabled women's entrepreneurship highlights new directions for exploring experiences of entrepreneuring at the intersection of disability and gender. The paper brings disability into view as a social category that should be of concern to feminist entrepreneurship researchers by surfacing different dimensions of experience to those currently explored. Through the new directions outlined, future research can further disrupt the prevailing discourse of individualism and meritocracy that perpetuates success as an individual's responsibility, and instead offer the potential for richer understandings of entrepreneuring which has a gender and disability consciousness.

Keywords: Entrepreneurship, intersectionality, gender, disability, impairment, anomalous body, sexuality, care. 


\section{Introduction}

Despite women's entrepreneurship research encouraging scholars to expand upon the questions asked and approaches taken (Ahl, 2006; Hughes et al., 2012); and the growing feminist disability studies (FDS) literature outlining the importance of including disabled women in feminist research and debates on intersectionality, there is a dearth of studies exploring the intersection of gender and disability within entrepreneurship research. Gender studies have made important contributions to the entrepreneurship field, yet significant challenges remain. The two challenges this paper will focus upon are, firstly, how women are positioned as lacking and deficit within the discourse of entrepreneurship (Ahl and Marlow, 2012) and secondly, that disabled people' $\mathrm{s}^{\mathrm{i}}$ experiences remain marginal to entrepreneurship research. This is despite both entrepreneurial and intersectional studies suggesting it is important to move away from conceptualizations of women as an homogeneous subject of analysis (Díaz García and Welter, 2011; Godwyn and Stoddard, 2011; Welter, 2011, 2012), as this masks the differences between women who may simultaneously experience gender and other categories of social difference (Holvino, 2010).

This paper responds to Ahl (2006), Fayolle et al. (2016) and Hughes et al.'s (2012) call to extend women's entrepreneurship research agenda by addressing the need for further studies which explore non-traditional questions by taking a feminist constructionist approach committed to the inclusion of diverse voices. Within entrepreneurship studies, there are calls for greater critical, and in particular, feminist analysis (Ahl, 2006; Ahl and Marlow, 2012; Blackburn and Kovalainen, 2009; Eddleston and Powell, 2012; Marlow et al., 2009; Mirchandani, 1999; Welter, 2011). Bourne and Calás (2013) highlight the potential to advance the field by exploring the gendered nature of entrepreneurship and how gender is (re)produced within particular social contexts. This requires an understanding of gender as socially constructed to illuminate the relationship between gender, entrepreneurial complexities and different contexts in order to appreciate an entrepreneur's agency and structural constraints which influence such contexts (Welter, 2011; 2012). This paper recognizes that entrepreneurship is not open and accessible to all, and develops a feminist approach to expose gendered and ableist practices to offer theoretical insights and avoid "a dead end" within the field (Ahl and Marlow, 2012, p. 555). 
It is necessary to explore social categories as it is recognized they construct distinctions and differences which shape the spaces and places available to people and thereby make a difference to experiences and the construction of social relations (Mumby and Clair, 1997). However, the entrepreneurship field lacks research which explores such differences. Godwyn and Stoddard (2011) contend that gender and minority status shape entrepreneurial experiences, therefore further research is necessary whereby neither category is prioritized over another. This paper offers an intersectional approach to provide new theoretical insights to the entrepreneurship field which does not prioritize either category and recognizes the complexities that social interpretations of 'gender' and 'disability' have for future entrepreneurship studies. Gender is a social practice (Bruni et al., 2004a; 2004b) which is (re)produced in everyday interactions (Acker, 1992). Yet (unconscious) societal interpretations conflate gender with sex, tying masculinities and femininities to the bodies of men and women respectively, thus leading to social role incongruence within the gendered process of entrepreneurship (Swail and Marlow, 2018). This paper understands disability from a social interpretation perspective (Author and Colleague, 2012) which acknowledges impairment as cognitive and physical variation from normative expectations (without any associated value judgement) (Thomas, 2007). Disability is recognized as the social marginalization of people living with impairment whose experiences are contextually (negatively) mediated by social, material or cultural influences (Author and Colleague, 2012).

There are a limited number of studies which have focused upon disabled entrepreneurs and selfemployment (e.g. Pagán, 2009; Cooney, 2008; Pavey, 2006; Ipsen, et al., 2005; Boylan and Burchardt, 2002) despite disabled people being more likely to be self-employed than non-disabled people (Boylan and Burchardt, 2002; Cooney, 2008). Kitchin et al., (1998) argue that those who do draw upon labour market government statistics, do not explore experiences of disability, thereby creating space for qualitative in-depth studies to explore experiences of disability within entrepreneurship. Nor do they address the particular experiences of disabled women entrepreneurs. Within the few studies exploring self-employment within the disability field disabled entrepreneurs are treated as a homogenous group of 'disabled entrepreneur', assumed to be predominantly male, perpetuating the gender-blind disability 
literature (Jolly 2000) and masculine dominance within the entrepreneurship field (Ahl, 2002, 2006; Hamilton, 2013; Lewis, 2006; Mirchandani, 1999).

The need for intersectional studies to facilitate positive social change is highlighted most pertinently by Shields (2008). She argues that intersectionality forces researchers to view the world from alternate perspectives, thereby pushing research agendas further, which in turn provides the supporting data to inform policy which creates the possibility for social change to occur. Kitching (2014) argues barrriers to entrepreneurship may be compounded by gender and his call for policy action on disability supports Shields' (2008) feminist plea for greater intersectional research, as Shields emphasizes the need for disability to be explored alongside other measures to address the disadvantages experienced by incumbents of varying categories of difference.

The research question which guides this study is how can gender and feminist disability theory contribute to the development of an intersectional theoretical lens for future entrepreneurship research? By surfacing different dimensions of experience to those currently explored in the field, this paper extends the debates on women's entrepreneurship research by offering a theoretical intersectional disability and gender lens. The lens facilitates a consideration of contextual factors and highlights the potential for new insights to emerge in the women's entrepreneurship field. The paper does so by firstly considering key issues within the extant women's entrepreneurship research, highlighting current criticisms. The paper then outlines the conceptual potential of intersectional studies before exploring the feminist disability studies literature to identify key issues to incorporate in the intersectional lens. The paper draws to a close offering a contribution in the form of an intracategorical intersectional lens to surface theoretical synergies and variances at the intersection of gender and disability within entrepreneurship. 


\section{Women's entrepreneurship research: Contemporary debates}

It is widely recognized that concepts of 'entrepreneurship' and 'entrepreneur' have been historically and culturally (re)produced on masculine terms (Ahl, 2002; Ahl and Marlow, 2012; Mirchandani, 1999; Bruni et al., 2004a, 2004b; Lewis, 2006, 2009). Consequently, women and men have learned to become entrepreneurs against the masculine norm. The masculine norm is utilized as the "yardstick" (Mirchandani, 1999, p. 233) to measure the extent to which both women and men demonstrate 'successful' - masculine - entrepreneurial traits and behaviours (Mirchandani, 1999; Simpson and Lewis, 2005). This presents a paradox for women as they are never able to fit in as they embody difference and jolt assumptions of what is deemed acceptable entrepreneuring within a female body (Ahl and Marlow, 2012). Hughes et al. (2012) outline three key criticisms of the extant literature: an overreliance upon the economic growth argument, an individualistic orientation and the dominance of objectivist studies. This paper uses Hughes et al.'s (2012) framework, and Ahl's 2006 seminal study, as heuristic tools to consider the implications of the economic growth rationale; individualism; objectivist studies and sex comparison studies (Ahl, 2006) to set the context upon which an intersectional lens is developed for entrepreneurship research.

\section{$\underline{\text { Economic growth rationale }}$}

The economic growth rationale positions women as an "untapped pool of entrepreneurial talent" (Marlow, 2006, p. 399) which, if utilized, has the potential to secure economic vibrancy (DTI, 2003; Harding, 2007). Consequently, the economic growth argument has been given precedence over other drivers for women entering entrepreneurship such as flexibility, work life balance, and independence. However, despite both women and men being inclined to start-up and run small businesses, a nongrowth orientation, deemed to be non-entrepreneurial and inferior (Lewis, 2006) is positioned as a women's problem (Ahl, 2006; Lewis, 2006; Lee-Gosselin and Grise, 1990). There has been much support for the need, and availability of, entrepreneurship studies focusing upon financial performance of women's businesses (Ahl, 2006; de Bruin et al., 2007). The unfortunate consequence of the financial 
focus has resulted in alternative research questions and approaches being silenced (Hughes et al., 2012) or suppressed.

Individualism and meritocracy

The predominance of an individualistic orientation both theoretically and methodologically (Ahl, 2006; Ahl and Marlow, 2012; Hughes et al., 2012) has resulted in contextual and historical constraints being overlooked, perpetuating the gendered nature of the field (Ahl, 2006). A liberal feminist perspective might argue that if a gender neutral perspective was adopted, then women would be able to access the same opportunities as men (Ahl, 2006; Marlow and Patton, 2005). This position draws upon discourses of meritocracy and individualism which refute claims of gendered contexts, preventing women from attributing their experiences to "collectively experienced barriers" (Kelan 2008, p. 435). Meritocracy also assumes individualism, understood to suggest individuals' free choice and control over both their personal and professional lives (Kelan, 2008) with opportunities for both success and failure. Merit, therefore, enables the exercise of individualism where the assessment of an entrepreneur is based upon objective criteria of personal input and effort (Kumra, 2010; Lewis, 2006). Whilst this has been a strong discourse in the literature, merit is now recognized as a gendered concept, where the profile of individuals who have been successful in the past determines the profile for those who are successful in the future, and any deviance from this norm is overlooked, devalued and invisible (Kumra, 2010). A theoretical patriarchal backcloth is understood to precede individual choice and dictate the limits against which an individual may attempt to exercise their agency (Thomas and Linstead, 2002). Consequently, this perspective would perpetuate associations of success with men whilst positioning women's continued inequality as a result of their individual lack of merit or motivation to take advantage of the opportunities presented, thereby absolving the privileged group of any responsibility (Lewis, 2004). This serves to disguise the continued gendered nature of entrepreneurship as "women are held accountable for structural circumstances beyond their control" (Ahl and Marlow, 2012, p. 545).

McRobbie (2015) argues there has been a renewed emphasis on individualism. She suggests that women's success is based on an illusion of control - at home, work and family - and idea of 'the 
perfect', an aspirational idea of the good life. As Gerodetti and McNaught-Davis (2017) also highlight, the post feminism/neo liberal perspective maintains this discourse, positioning success as individuals' responsibility to apply sufficient effort and make appropriate choices, thus maintaining the ideal of the self-made subject. The reliance upon a discourse of individualism conceals other categories of difference, positioning all women as having the same opportunities and resources, perpetuating the neo liberal individualism understanding that success is premised on choice, effort and success (Gerodetti and McNaught-Davis, 2017). This neo liberal narrative is harmful (McRobbie, 2015) as it affords power structures of gender and disability invisibility, therefore the shortcomings are attributed to individuals rather than social structures $(\mathrm{Ahl}, 2006)$. This paper argues that entrepreneuring is too often assumed to be open to all, failing to acknowledge the gendered restrictions placed upon women (Ahl and Marlow, 2012), and as this study adds, upon disabled women.

\section{$\underline{\text { Objectivist studies }}$}

Hughes et al. (2012) argue that the dominance of objectivist ontology and epistemology within studies of women entrepreneurs contributes to rendering masculine dominance invisible and serves to essentialize women and men. Such studies fail to acknowledge the social construction of gender and gendered expectation or to recognize how the different social contexts in which women are located have implications for their perceived success. Objectivist orientated studies fail to distinguish between sex category and gender behaviour (Messerschmidt, 2009), relying upon an understanding of gender as biologically determined, whereas constructionist perspectives conceptualize gender as any expected or perceived differences between women and men to be socially, or culturally learned, mediated or constructed (Sunderland, 2004). Constructionist approaches are concerned with how assumptions about the principles, values, and attributes which are associated with masculinity and femininity have implications for people who are assigned as man or woman (Alvesson and Billing, 2009). As a category of social relations, gender is also recognized to be hierarchical with social locations of One and Other (de Beauvoir, 1972). One of the binary pair is recognized as the norm, and associated attributes and values establish social norms, to the negation and marginalization of those people considered Other. It 
is recognized that this social ordering of relations is embedded within expectations and responses to entrepreneurship (Ogbor, 2000).

\section{$\underline{\text { Sex comparisons }}$}

Finally, the abundance of sex comparison studies within women's entrepreneurship research (Marlow et al., 2009), measure psychological, trait, behavioural differences (Ahl 2006; de Bruin et al., 2007) and different motivations and barriers (Simpson and Lewis, 2005) between men and women. This serves to perpetuate the perception of essentializing differences between women and men entrepreneurs by continually treating them as homogenous subjects (Diaz Garcia et al., 2011; Welter, 2011, 2012). Roomi et al. (2009) argue that the field has become characterized by the challenges women face, in particular family responsibilities and a lack of financial, social and human capital which are cited as key reasons for poor performance and growth. For over two decades flexibility has been noted as a central motivating factor for women to enter entrepreneurship to fit working activities around family commitments e.g. from Brush (1992) to Eddleston and Powell (2012). However, this understanding essentializes and perpetuates women as the primary carer assuming that all women are driven by a narrow set of familial concerns (Lewis, 2009). For women's entrepreneurship studies to develop theoretically, a move beyond the essentialist, or functionalist, paradigm is required in order to include more qualitative and reflexive approaches (Blackburn and Kovalainen, 2009), which explore entrepreneurship as a cultural phenomenon (Bruni et al., 2004a, 2004b). Ahl (2006) contends future research must capture the richer aspects of women's entrepreneuring by exploring issues which account for the broader social context and how gendering is (re)constructed, which resonates with the feminist perspective and understanding of gender within this paper. Furthermore, this paper appreciates Blackburn and Kovalainen's (2009, p.132) encouragement of scholars to engage in reflexivity to increase understanding of how "linguistic, social, political and institutional forces come together to generate knowledge in small business and management research", to understand relations between contexts (Welter, 2011, 2012) and how gender and minority status may shape entrepreneurial experiences (Godwyn and Stoddard, 2011). 
Cognizant of the above criticisms and proposed ways of developing the field, it is imperative that new theoretical insights and alternative ontological and epistemological perspectives are valued within women's entrepreneurship research. Whilst including women within entrepreneurship studies has served to recompense women's exclusion (Simpson and Lewis, 2005) and place them firmly "on the enterprise map" (Marlow et al., 2009, p. 140), comparative studies have failed to challenge the gendered understanding of entrepreneur and entrepreneurship. Greater attention is therefore required to explicate power relations within women's entrepreneurship research by acknowledging contextual, historical and socio-cultural influences (Chell and Baines, 1998). Appreciating gender as a socially constructed category of social relations (Fayolle et al., 2016) enables the exploration of gendered language use and how this sustains masculine hegemony, affecting the potential opportunities and experiences of entrepreneurship and research.

Hughes et al. (2012), extending Ahl (2006), suggest there is a need to ask different (non-traditional) questions within the field by outlining alternative questions and approaches. It is within this spirit, and Hughes et al.'s (2012) framework, that this paper proposes the inclusion of an additional category of difference to analyse experiences of entrepreneurship to provide new directions for entrepreneurship research. Despite disabled people being more likely to be self-employed than non-disabled people (Boylan and Burchardt, 2002; Cooney, 2008), there is a surprising lack of studies focusing upon disabled entrepreneurs and self-employment (e.g.Cooney, 2008; Pavey, 2006). This paper contributes to addressing this gap through an intersectional gender and disability lens as an approach which fits within Hughes et al.'s (2012) call for non-traditional questions, contextual explanations and constructionist approaches. This paper contends that whilst disability has been included within some entrepreneurship research, such studies have failed to account for recent reconceptualizations of disability, or the implications of heterogeneity between women, despite this being surfaced as an important consideration in context sensitive entrepreneurship research (e.g. Godwyn and Stoddard, 2011; Welter, 2011, 2012). To demonstrate this gap the paper now reviews entrepreneurship studies which incorporate disability. 


\section{Studies of entrepreneurship and disability}

Whilst the disability and entrepreneurship literature has explored the concept of entrepreneur, it is limited to a focus upon an individualistic conceptualization (Cooney, 2008); neglecting different contexts and the complexities this brings to experiences of entrepreneurship. Pavey (2006) for example problematizes entrepreneurship studies through a critique of the use of the concept of capital, arguing it is premised upon an individualistic understanding, which fails to consider the impact of disability on the potential to develop capital.

It is recognized that social inclusion, including access to employment and social activities, contributes to social capital which correlates to positive outcomes (Blackmore, 2007; Williams et al., 2011). However disabled people face a range of barriers to inclusion in social activities (Williams et al., 2011), gaining educational qualifications and maintaining employment (Burchardt, 2000, 2003; Foster, 2007; Harlan and Robert, 1998; Pavey, 2006), all of which are recognized as necessary to offer opportunities for the development and deployment of capital.

A number of studies raise a concern for the negative impact of disability upon business performance. Whilst some studies consider financing of disadvantaged entrepreneurs (Rouse and Jayawarna, 2006), and microfinance services used by disabled people in developing countries (Beisland and Mersland, 2012; De Klerk, 2008), there is a suggestion that disability is a burden for entrepreneurship more generally. For example in the UK, the Disability Discrimination Act (DDA) exemption for small businesses with 20 employees or less suggested disability was perceived as an unreasonable burden for smaller sized SME employers who constituted $95 \%$ of employers at the time (Goss and Goss, 1998).

Cooney (2008) argues that disability is the forgotten minority within studies of entrepreneurship even though disabled people are more likely than non-disabled people to be self-employed (Boylan and Burchardt, 2002; Cooney, 2008). Given these higher rates of self-employment for disabled people, there is a real need to encourage a disability research agenda (Pagán, 2009) and thereby inform entrepreneurship policy recognizing the diversity of impairments (Kitching, 2014), which Shields (2008) argues will facilitate social change. This agenda is also supported by Boylan and Burchardt's 
(2002) earlier UK study which also notes higher rates of self-employment for disabled women (8\% compared to $6 \%$ for non-disabled women) and men (18\% compared to $14 \%$ for non-disabled men). Niekerk et al.'s (2006) study suggests disabled entrepreneurs' motivation is more out of necessity to overcome dissatisfaction, gain greater flexibility and empowerment beyond that available in standard employment.

To address the disabled entrepreneurship literature gap, this paper draws on the feminist disability studies (FDS) literature to identify contextual and conceptual factors which are not yet addressed within the women's entrepreneurship field. In doing so this paper outlines an intersectional approach which recognizes gender and disability as shaping opportunities for entrepreneurship, an approach to which this paper now turns before outlining our understanding of disability and key insights from FDS.

\section{An intersectional approach}

Since Crenshaw's (1991) call for the need to explore multiple categories of social difference (e.g. gender and race), the intersection of such categories has become a growing area of interest in feminist studies to explore the multiple dimensions and complexities of the ways in which categorizations are constructed, as well as the experiences of incumbents of these categorizations (McCall, 2005). Subsequent intersectional studies have focused upon categorizations such as race, gender and class (Holvino, 2010), Islam, gender and ethnicity (Essers and Benschop 2009), and ethnicity, gender and race (Healy et al., 2011). However, disability as a social category remains under explored since Zanoni's (2011) study of gender, disability and age in an automotive factory. This may be because disability is a recent addition to organization studies research concerned with the theorization of social categories of difference (Author and colleague, 2012).

McCall's (2005) outline of different approaches to intersectionality is drawn upon to develop an intersectional conceptual lens which includes disability for studies of women entrepreneurship and to inform the conceptual framework of this paper. McCall (2005) suggests three broad intersectional approaches categorized as: anticategorical, intercategorical and intracategorical complexity. 
Anticategorical approaches focus upon critiquing categories through deconstruction as the complexities of social life are thought to be irreducible. This means understanding social categories as nothing more than social fictions which through their creation and use produce social inequalities. Secondly, intercategorical complexity approaches use existing social categories for analytic purposes to understand and effect changes in inequality for different social groups "among social groups and changing configurations of inequality along multiple and conflicting dimensions" (McCall, 2005, p. 1773). Thirdly, intracategorical approaches are critical and questioning of processes of category construction whilst also recognizing that the categories represent enduring relationships, through a focus on "social groups at neglected points of intersection" (McCall, 2005, p. 1774).

This paper draws upon the intracategorical approach in the construction of the conceptual lens for the study of disabled women entrepreneurship and takes forward two of the three foci often explored in early studies using such an approach. That is, it explores a concern for a particular social group (women) at a "neglected point of intersection" (disability) within "a particular social setting" (entrepreneurship) (McCall 2005, p. 1780). The strength of this perspective, McCall (2005) suggests, is to provide insights into the experiences of social relations for the social group concerned, particularly when taken forward through case studies which provide an understanding of variation over homogeneity, and complexities and differences in experiences within the group as well as between the group and others. This is particularly useful when exploring the experiences of disabled women as there may be significant variation in the impairments disabled women live with, which shape their expectations, requirements, and approaches to negotiating (Author and Colleague, 2012) entrepreneurship contexts. Reflecting other intracategorical approaches (McCall, 2005) the social categories of women and disabled are used with scepticism in this paper, maintaining a concern for how these categories of social relations are produced and the effects they have upon the opportunities and experiences of incumbents of such categorizations. 
Having outlined key issues in the women's entrepreneurship literature and our understanding of intersectionality, the paper further expands the conceptualization of disability, impairment and ableism, before turning to the key contributions from FDS research.

\section{Social interpretation of disability}

As outlined in the introduction, this paper draws upon a social interpretation of disability which interprets impairment as bodily and cognitive variation and disability as the social marginalization of people living with impairment. Historically, a medical/individualized interpretation of disability has been the dominant discourse of disability which interprets disability as a consequence of physical or cognitive impairment, requiring rehabilitation in order to achieve social inclusion (Oliver, 1983, 1990). This interpretation is critiqued as conforming to non-disabled ideals of 'being normal' (Oliver, 2009).

The social interpretation of disability similarly shifts attention away from impairment as the source of disability towards a critique of the social relations and practices that assume able-bodiedness and thus marginalize disabled people (Campbell, 2009), using the concept of ableism to express the assumption of non-disability as an organizing norm (Author and Colleague, 2012). Ableism is a recent addition to studies of disability adding a concern for the "ideas, practices, institutions and social relations that presume ablebodiedness and position disability as inability" (Author and Colleague, 2012, p. 171).

The social interpretation outlined here suggests impairments are not deficits (Gray, 2009), but legitimate differences (Overboe, 1999) which shape disabled people's work related organizing requirements. The onus is thus upon the organizational context to include disabled people's impairment related requirements rather than to expect disabled people to seek remedial action such as making adjustments to current practices on an adhoc basis, which fails to challenge ableist assumptions of the normative (non-disabled) body. This social interpretation therefore focuses attention on how ableism shapes opportunities for work (and by extension entreprenurship) and suggests there is an obligation to enable 
disabled people "in their project of being bodily present, acknowledged, accommodated and enabled ... in organizational life" (Cockburn, 1991, p. 212).

In developing this intracategorical lens for entrepreneurship it is necessary to be critical of concepts such as disability as a means of defining a group of people (Author and Colleague, 2012). This approach echoes feminist concerns to develop a common language to explain experience whilst simultaneously cautioning against being overly tied to categorizations which can become fixed and therefore potentially totalizing and homogenizing (Shildrick, 2009). Concepts such as woman/disabled are problematic, but also necessary as a means of being able to talk about the experiences of people who are socially classified through these terms (McCall, 2005; Shildrick, 2009). This paper suggests the answer is to adopt a temporal approach which is sensitive to these complexities, refutes fixed and bounded categorizations and queries the normative paradigms which shape the social imaginary (Shildrick, 2009). This reflects an appreciation that disability is socio-historically contextual (Shildrick, 2009) and facilitates a deeper understanding of disability as constructed and negated difference inextricably bound to assumptions of ableism. It is therefore necessary to critique the normative assumptions underpinning organizing processes of entrepreneurship to understand how disability is constructed as a negated difference to facilitate feminist intersectional studies of women's entrepreneurship. To do so the paper turns first to contextualizing the FDS relationship to broader feminist theorizing and mainstream disability theorizing.

\section{Feminist Disability Studies}

Whilst it has been long recognized by FDS scholars that feminist theorizing and praxis needs to incorporate and address disability (Morris, 1993a; Rohrer, 2005), there remains scope for research to engage with FDS to develop new research agendas which incorporate disabled women's experience (Thomas, 2006). Within Disability Studies FDS scholars also identified mainstream disability research has been overly centred on the social and economic exclusion of disabled people and "the experience of disabled men...[as] representative of the disabled experience in general" (Morris, 1993b, p.85). This 
focus marginalized accounts of experience and maintained a private/public divide, which FDS scholars identified as problematic as it excluded a range of issues disabled women felt were important to address. This paper therefore draws upon the FDS critique of both wider feminist studies and mainstream disability studies to explore issues which are important to the development of an intersectional lens on entrepreneurship to challenge assumptions which contribute to disabled women experiencing difficulties in gaining access to entrepreneurial opportunities and economic security. To do so we further develop the social interpretation of disability outlined above for entrepreneurship research by drawing key issues from the FDS literature through three key themes. Firstly the move from macro to micro perspectives to incorporate the anomalous body by including experiences of impairment; secondly to argue for the legitimization of multiple experiences of care in the social sphere and thirdly to the theme of sexuality, beauty and appearance.

The anomalous body through experiences of impairment

Mainstream disability research has historically emphasized the impact of economic structures and how these contributed to disabled people's economic exclusion (Burchardt, 2000). This macro level analysis reflects disability studies' critique of capitalist social and economic structures as a contributing factor to disabled people's marginalization (Oliver, 1990). Feminist scholars argue however, that a macro level focus contributes to the private/public divide in disability theorizing (Morris, 1993a, 1993b; Thomas, 1999) and led to the exclusion of experiences of impairment from disability theorizing (Begum, 1992; Crow, 1996; French, 1993; Thomas, 1999, 2001). Fawcett (2000, p. 119) suggests this macro perspective reinforces a view which omits difference between disabled people and re-asserts a "male-orientated...sameness", in theorizing which fails to "unsettle notions that some areas of social life are 'private' or 'presocial'”' (Thomas, 1999, p. 69).

Highlighting experiences of impairment as a social as well as a subjective experience (Goodley, 2001) is therefore a necessary inclusion to the theoretical focus of intracategorical research in entrepreneurship 
studies. As Hughes (2007, p. 678) explains "impairment is the vantage point from which disabled people see the world" therefore understanding disabled people as knowledge producers whose experiences can inform theoretical developments is essential (Campbell, 2009; Hughes, 2007; Oliver, 1983, 1990, 1996; Thomas, 2007). Recognizing the legitimacy of impairment effects requires future feminist entrepreneurship research to acknowledge what women entrepreneurs "seek to have recognized and mainstreamed within their organizing contexts" (Author and Colleague, 2015, p. 130).

\section{Legitimizing care in the social sphere}

The social and political organization of care is historically associated almost exclusively with women who perform caring responsibilities within the private family context, an issue which has progressively become a societal ethical concern (Gherardi and Rodeschini, 2016; Kittay et al., 2005). However, the critique of women as largely responsible for the care of others has failed to account for disabled women who are sometimes recipients of such care for their impairment related requirements (Morris, 1991, 1993c, 1996). This reflects a broader critique that disabled people's impairment related self-care is an everyday aspect of experience which is unacknowledged in the public sphere, particularly in relation to work (Barnes and Mercer, 2005). Care is not only an issue of "taking care of another", but also that humans "are selves oriented to others", who offer and require solicitous care (attentiveness, considerate and careful treatment) (Gherardi and Rodeschini (2016, p. 2). Rather than perceiving care as a burden, an orientation and acceptance of the need for solicitous care is a core element of being human. Caring in this sense is a necessary "organizational competence" enacted through everyday activities as a collective achievement (Gherardi and Rodeschini, 2016, p. 266).

This suggests moving the logic of care from the private to the public sphere alongside a general orientation towards solicitude to acknowledge disabled women entrepreneurs' multi-faceted experiences of care which differ from non-disabled women; as care-givers, care-recipients (from others including health care specialists) and/or care-takers in respect of their own impairment related requirements. Such requirements may entail high levels of flexibility for disabled women entrepreneurs; in their work remits, factoring in time to the working day for impairment related self-care, or flexibility 
from those with whom disabled women work within entrepreneurship contexts. As such the logic of caring can become inscribed in practices moving it from the private to the public sphere of entrepreneuring, legitimizing the impairment related needs of disabled women entrepreneurs as well as an orientation to care to counter the neoliberal logic of choice (Gherardi and Rodeschini, 2016; Mol, 2008).

\section{$\underline{\text { Sexuality, beauty and appearance }}$}

Whilst the impaired body's requirements has lacked social codification, disabled people's bodies are simultaneously, highly scrutinized, regulated and shaped through social practices (Garland-Thomson, 2002; Tremain, 2005), particularly around issues of sexuality (Shildrick, 2009). This paper contends patriarchy and assumed heterosexuality are as equally important for disabled women as women in general, although this manifests in different ways. As noted above, gender is understood as the expected or perceived differences between women and men which are socially constructed, reflecting assumptions about principles, values, and attributes associated with femininity and masculinity (Alvesson and Billing, 2009). It is also argued that "formally desexualized" organizational life is imbued with sexuality (Fleming, 2007, p. 239) which plays a central role to power relations in organizational life (Burrell, 1984: Burrell and Hearn, 1989).

If sexuality is an integral element of gendered assumptions, disability complicates the principles, values, and attributes associated with gender, sex and femininity. It is argued that disabled people are desexualized (Begum, 1992; Shakespeare et al., 1996; Campbell, 2017), yet simultaneously seen as hypersexual/deviant, or objects of fetishism (Liddiard, 2011; Shakespeare et al., 1996), exceeding, or transgressing the parameters of assumed heteronormative expectations (Shildrick, 2009). Disabled women are disempowered by sexual norms associated with femininity as their impaired bodies distance them from feminine ideals, even if they continue to uphold these ideals for their own sexual identities (Liddiard, 2011). Disabled women therefore have to work to (re)claim sexual identities in the public sphere, and manage non-disabled voyeurism and curiosity in social interactions; surfacing the complexities generated through a theoretical lens of disability, gender and sexuality. This is important 
as it is argued that our sense of self is tied up with acting out sexuality as "the capacities of the body and psyche are given meaning only in social relations" (Weeks, 1986, p. 15). Sexuality is therefore recognized as an ordinary public process and an aspect of body politics which is intimately tied up with gender power im/balances (Burrell and Hearn, 1989). This literature highlights the importance of sexuality for disabled women entrepreneurs in surfacing how sexuality and gender are intertwined, with implications for the potential to negotiate gendered expectations when entrepreneuring.

Garland-Thomson (2002) identifies a further dimension that this paper suggests is important to intersectional entrepreneurship; the regulation of women's and disabled people's bodies and how this extends from medicalizing the body to beauty norms associated with personal appearance. Having been historically perceived as sick or abnormal, disabled people have been subjected to high levels of medical intervention to remedy their 'deviant' bodies (Garland-Thomson, 2002). FDS focuses on denaturalizing standardized assumptions of normality through an acceptance of bodily variation and by adopting a criticality towards corrective measures such as reconstructive surgery which reproduce and reinforce expectations of normality. Whilst women in general are recognized to be subjected to sexist expectations to conform with Western beauty norms (Forbes et al., 2007), such beauty norms, as an aspect of the politics of appearance, can be internalized as personal inadequacy by disabled women when they are perceived to not meet such norms (Rohrer, 2005). This is particularly so when impairments are visible (Garland-Thomson, 2002). Incorporating these issues into feminist entrepreneurship would go some way to politicizing appearance and recognizing that social discrimination is connected to the de/valuing of particular forms of women's appearance with material consequences.

\section{A gender and disability intersectional lens for entrepreneurship}

This paper has explored key themes and criticisms within women's entrepreneurship research and FDS which brings disability into view as a social category of concern to feminist entrepreneurship researchers, by surfacing different dimensions of experience to those currently explored in the field. As 
Thomas (2006) suggests, disability should not be nominally included as a difference amongst other differences which then receives little sustained analysis. This paper argues that the issues raised address calls in feminist entrepreneurship studies to provide spaces for alternative research approaches and questions to emerge (Fayolle et al., 2016; Hughes et al., 2012). By moving beyond neo liberal understanding of success, premised upon merit, choice and the 'illusion of control' (Gerodetti and McNaught-Davis, 2017), the influence of social structures can be brought into view (Ahl, 2006; Fayolle et al., 2016; McRobbie, 2015) to challenge gendered understandings of entrepreneurship.

The paper connects with calls for entrepreneurship to be understood as a cultural phenomenon (Bruni et al., 2004a, 2004b) enabling a critique of the strong association between entrepreneurship and masculinities and moves towards a relational understanding of entrepreneurship as an emergent process. This appreciates that entrepreneurship is not an individualistic endeavour, as opportunities and assessments of those engaging in entrepreneurial activities are contextually influenced and shaped through the gendered social order (Ahl, 2006; Chell and Baines, 1998; Kumra, 2010; Lewis, 2006). This gendered understanding helps us to appreciate women's place on the margins in society which is reflected within entrepreneurial opportunities and activities.

The intersectional approach suggested by this paper reflects calls for entrepreneurship research to be reflexive (Blackburn and Kovalainen, 2009) by problematizing individualized and medicalized approaches to disability, offering a social interpretation and adopting McCall's (2005) intracategorical approach. This approach examines the intersections of women, disabled and entrepreneurs, and privileges variation over homogeneity, complexities and differences in experiences between women as well as with others, and encourages scepticism of the ways in which the categories women and disabled are (re)produced and experienced in the context of entrepreneurship. This paper suggests adequate exploration of the experiences of disabled women entrepreneurs at the intersection (McCall, 2005) requires engagement with FDS which surfaces different dimensions of women's experiences beyond feminist critiques of entrepreneurship as well as acknowledging shared theoretical concerns. 
This review offers a gender and disability intersectional lens for entrepreneurship which identifies new directions for entrepreneurship research. Through an intracategorical lens of gender and disability the key issues identified from feminist entrepreneurship and feminist disability studies problematize language and homogeneity of categories of differences which make a difference (Mumby and Clair, 1997). Through the lens four theoretical synergies and three theoretical variances are identified (see figure 1).

\section{(INSERT FIGURE 1)}

\section{Theoretical synergies}

The four theoretical synergies identified are: economic rationale, flexibility, individualism and meritocracy, and social and human capital. These synergies are often cited and explored as motivations for encouraging more women to engage in entrepreneurship but there is little research exploring the everyday manifestations of how the synergies are experienced within entrepreneurship. Furthermore, exploring the importance of the synergies for disabled women entrepreneurs has the potential to highlight similarities and differences which will further explicate the complexities of disabled women's entrepreneurship experiences as well as extend and contribute to the broader feminist entrepreneurship agenda. This paper offers questions for further research for each of the identified synergies (drawn together in Table 1) to encourage scholars to disrupt the power structures shaping disabled women's experiences of entrepreneuring.

Firstly, despite the economic rationale being a topic that has already gained great coverage in both women entrepreneurship and disability studies fields, further exploration of how this is manifest within women's experiences of entrepreneuring will facilitate research from a different position which does not assume economic reasons as a main driver or indeed of how entrepreneurial success is interpreted. Instead, exploring how an economic rationale influences the choices and decisions made, as well as explicating the extent of control disabled women have over their economic experiences would provide new insight. 
Secondly, flexibility is a further synergy that is often cited as a main driver for women and disabled people entering entrepreneurship. How disabled women experience flexibility in their everyday realities will provide an understanding of its importance as well as where and how this can be accomplished. Understanding how disabled women make sense of this in relation to their choices to enter entrepreneurship and the control they experience within this space will extend knowledge of this well cited driver.

Thirdly, problematizing the prevailing discourses of individualism and meritocracy within the intersection of gender and disability in entrepreneurship disrupts the neoliberal/post-feminist position of choice, control and merit being determined by individual effort. Rather, it opens up a space from which to explore how discourses of individualism and meritocracy manifest within disabled women's experiences of entrepreneuring. Furthermore, exploration of how disabled women construct perceived choice, control and merit, and, in what spaces, processes and conditions these occur would extend our understanding of their entrepreneuring experiences.

The final synergy and suggested area of research is the further study of various forms of capital (including social and human capital) in terms of how it is developed and maintained by disabled women through entrepreneuring, would offer new insights. Exploring the potential to research this through the inclusion of additional categories of difference (for example social class) would enable an appreciation of how social structures shape and influence entrepreneuring experiences and attempt to further disrupt the masculine norm in entrepreneurship.

The research questions these synergies generate appreciate that success is socially constructed based on an illusion of control and an aspirational idea of a good life (McRobbie, 2015). Exploring how each synergy is manifest within disabled women's experiences of entrepreneuring will help illuminate constraints which might otherwise remain invisible. In particular, research questions which focus on disabled women's sense making of their entrepreneuring choices and how each synergy influenced that choice will elucidate how much perceived control disabled women have within and through varying spaces and processes. In doing so, future research can begin to disrupt the prevailing discourse of 
individualism and meritocracy that perpetuates success as individuals' responsibility, and instead offer richer understandings of entrepreneuring which has a gender and disability consciousness.

The paper now turns to summise the theoretical variances identified through feminist disability studies to further extend the problematization of the masculinist discourse of entrepreneurship.

\section{Theoretical variances}

Through the FDS literature additional concerns, or variances, which are otherwise absent in the women's entrepreneurship literature have been identified: the anomalous body and bodily variation; multiplicity and simultaneity in experiences of care; and the scrutinized body. Considering how these variances impact upon disabled women entrepreneurs' expectations of their organizing contexts will prove to be generative in expanding a contextual approach to women's entrepreneurship.

This paper suggests that disability and ableism as a social category should be brought into view as relational, and mutually constitutive (Author and Colleague, 2012; Price and Shildrick, 2002) to appreciate the extent to which disability has historically been constructed as Other. This identifies assumed non-disability (ableism) as an organizing norm which has remained invisible to scrutiny. This orientation suggests the first variance of anomalous body and bodily variation by incorporating experiences of impairment for the gender and disability lens on entrepreneurship. This is recognized as helping to break a private/public divide for disabled women which has previously negated their experiences of the social world; argued to be imbricated by impairment (Campbell, 2009).

The second variance this paper has established is that disabled women can experience care in multiple and simultaneous ways: as care-providers within maternal or familial roles, but also as care-recipients, and as self-carers of impairment related requirements. While mainstream feminist literature has highlighted entrepreneurial activities as offering women flexibility as care providers (Author and Colleague, 2009) the implications of this for disabled women and of multiple and complex caring for their entrepreneurial activities is not yet understood. Therefore, exploring how disabled women move between and within processes of care and be acceptable, legitimate, and successful within 
entrepreneuring is an important consideration. Contextualizing this within an approach which recognizes solicitous care might facilitate the acceptance of disabled women's needs around these forms of bodily care as an important element to creating a more relational entrepreneurial environment. A relational approach is premised upon a concern for how individuals might orientate themselves to others, which would be beneficial in entrepreneurship contexts and contribute to challenging what success might look like through an acceptance of bodily variation and associated care needs, and enabling disabled women entrepreneurs to be 'more bodily present' (Cockburn, 1991).

The third variance relevant for disabled women is the scrutinized body, incorporating sexuality, beauty and appearance. Whilst sexuality has been shown to underpin normative gender expectations, and even be a defining organizational quality (Hearn and Parkin, 1987/1995, 2001), this paper suggests gendered appearance norms are potentially problematic for disabled women (Begum, 1992; Liddiard, 2011, 2014). Liberal feminist perspectives often adopt a gender neutral approach to entrepreneurship (Ahl, 2006; Marlow and Patton, 2005), therefore raising sexuality in the women's entrepreneurship literature may sit uneasily alongside mainstream concerns. However, this paper aligns with the view that gender and sexuality are fundamental to how people relate (Hearn and Parkin, 2001), and are therefore central concerns for a contextualized research agenda in the entrepreneurship field.

Future research could investigate the impact of perceptions of appearance on everyday interactions for disabled women entrepreneurs' ability to perform appropriate gender and entrepreneuring expectations (Bartky, 1990; Hall, 2001; West and Zimmerman, 2009). Specifically, how do disabled women construct their entrepreneurial identities in relation to success and what this might look and feel like when they embody differences from the male and able norm? Furthermore, how do disabled women manage and/or negotiate their sexuality and beauty to be acceptable, legitimate and successful in entrepreneuring? This adds to the recognition of the impact of sexuality in work organizations and suggests beauty norms as a further area of research for gender and entrepreneurship studies more broadly. 
There is significant potential to explore and provide further understanding of how disabled women entrepreneurs negotiate their appearance and bodily variations in their everyday entrepreneurial activities, as Hearn et al. (1989, p. 13) have argued, it is of central importance to recognize sexuality as "an ordinary and frequent public process rather than an extraordinary feature of private life...to see sexuality as one aspect of an all-pervasive 'politics of the body' rather than a separable, discrete set of practices". This paper suggests beauty norms are an important consideration for disabled women entrepreneurs and exploring disabled women entrepreneurs at varying stages of the entrepreneurial life cycle might prove useful to understand and appreciate differences amongst women.

The framework developed through the paper offers a gender and disability intersectional lens for entrepreneurship research providing a conceptual space where disabled women entrepreneurs' voices can be heard at the centre of the overlap between feminist women's entrepreneurship and FDS research. Four theoretical synergies and three theoretical variances are identified to generate questions for future research to empirically explore this intersectional space (see Table 1). Specifically, this paper problematizes perceived success based upon the illusion of choice and control (McRobbie, 2015) as an addition to the focus on gendered and ableist and homogeneity.

\section{[INSERT TABLE 1 HERE]}

\section{Conclusion}

This paper offers an intersectional lens to the study of disabled women's entrepreneurship to conceptually illuminate new directions for entrepreneurship research to explore experiences of entrepreneuring at the intersection of disability and gender. The gender and disability intersectional lens provides a contribution to the field through four theoretical synergies and three theoretical variances with new directions for entrepreneurship research outlined to highlight the theoretical and empirical potential. Future approaches to research might include in-depth, feminist, qualitative studies to explore the disability and gender intersections in entrepreneurship studies at varying stages of the entrepreneurial life cycle and from different perspectives i.e. the subjects themselves, their followers 
and or supporters. More broadly, this paper suggests the following research questions to further develop women's entrepreneurship literature. Firstly, what difference does disability as a constructed difference make for women entrepreneurs' experiences of entrepreneurship? Secondly, what influence do experiences of impairment, including experiences of being a care-recipient, and self-care have upon the ways in which women engage with and experience entrepreneurship? This paper suggests orientating ourselves to others with solicitude can facilitate a more inclusive context for disabled women's entrepreneurship. Thirdly, what are the implications of the politics of appearance, sexuality and beauty and the scrutiny and regulation of the anomalous body for disabled women's entrepreneurial experiences?

Exploring these questions through a focus upon disabled women entrepreneurs may also contribute more broadly to projects concerned with challenging the assumed masculine norm and constructions of success, to surface the ways in which bodies are socially mediated (Dale, 2005) through entrepreneurship. Finally, the intersectional lens offered encourages other scholars to conduct and explicate different intersections within different contexts and social categories. By drawing upon alternative theory bases it offers the potential to enrich our understanding of lived experiences of entrepreneuring by challenging normative assumptions through a greater critical appreciation of the ways in which entrepreneurship is constructed.

\section{References}

Acker, J. (1992), "Gendering organizational theory" in Mills, A. and Tancred, P., (Eds.), Gendering Organizational Analysis. Sage, London, pp. 248-260.

Ahl. H. (2002), "The construction of the female entrepreneur as the other," in Czarniawska, B. and Höpfl, H. (Eds.), Casting the Other: The Production and Maintenance of Inequalities in Work and Organizations, Routledge, London, pp. 52-67.

Ahl. H. (2006), "Why research on women entrepreneurs needs new directions", Entrepreneurship Theory and Practice, Vol. 30 No. 5, pp. 595-621. 
Ahl, H. and Marlow, S. (2012), "Exploring the dynamics of gender, feminism and entrepreneurship: Advancing debate to escape a dead end?”, Organization, Vol. 19 No. 5, pp. 543-562.

Alvesson, M. and Billing, Y.D. (2009), Understanding Gender and Organizations, $2^{\text {nd }}$ ed., Sage, London.

Barnes, C. and Mercer, G. (2005), "Disability, Work, and Welfare: Challenging the Social Exclusion of Disabled People", Work, Employment and Society, Vol. 19 No. 3, pp. 527-545.

Bartky, S. (1990), Femininity and Domination: Studies in the Phenomenology of Oppression, Routledge, New York.

Begum. N. (1992), "Disabled Women and a Feminist Agenda”, Feminist Review, Vol. 40 No. 1, pp. $70-84$.

Beisland, L. and Mersland, R. (2012), "The use of microfinance services among economically active disabled people: Evidence from Uganda", Journal of International Development, Vol. 24 No. 1, pp. 69-83.

Blackburn, R. and Kovalainen, A. (2009), "Researching small firms and entrepreneurship: Past, present and future", International Journal of Management Review, Vol. 11 No. 2, pp. 127-148.

Blackmore, T. (2007), "Half of my friends don't even see me as disabled': What can field, capital and habitus reveal about disability and inclusion? $\mathrm{PhD}$ dissertation, University of Exeter.

Bourne, K. and Calás, M. (2013), "Becoming 'real' entrepreneurs: Women and the gendered normalization of "work", Gender, Work \& Organization, Vol. 20 No. 4, pp. 425-438.

Boylan, A. and Burchardt, T. (2002), "Barriers to self-employment. Small Business Service, London.

Bruni, A., Gherardi, S. and Poggio, B. (2004a), "Doing gender, doing entrepreneurship: an ethnographic account of intertwined practices", Gender, Work and Organization, Vol. 11 No. 4, pp. 406-429.

Bruni, A., Gherardi, S. and Poggio, B. (2004b), "Entrepreneur-mentality, gender and the study of women entrepreneurs", Journal of Organisational Change Management, Vol. 17 No. 3, pp. 256-268.

Brush. C.G. (1992), "Research on women business owners: Past trends, a new perspective and future directions", Entrepreneurship Theory and Practice, Vol. 16 No. 4, pp 5-30.

Burchardt, T. (2000), Enduring Economic Exclusion: Disabled People, Income and Work, Joseph Rountree Foundation, York.

Burchardt, T. (2003), Being and Becoming: Social Exclusion and the Onset of Disability, London School of Economics, London.

Burrell, G. (1984), ‘Sex and Organizational Analysis', Organization Studies. Vol. 5 No.2, pp. 97-118.

Burrell, G. and Hearn, G. (1989), "The sexuality of organization”, in Hearn J., Sheppard, D., TancredSheriff, P. and Burrell, G. (Eds.), The Sexuality of Organization, Sage, London, pp. 1-28.

Campbell, F. (2009), Contours of Ableism. The Production of Disability and Abledness, Palgrave Macmillan, Basingstoke. 
Campbell, M. (2017), "Disabilities and sexual expression : A review of the literature", Sociology Compass, Vol. 11 No. 9, p. 1-19.

Chell, E. and Baines, S. (1998), "Does gender affect business 'performance'? A study of microbusiness in business services in the UK", Entrepreneurship and Regional Development, Vol. 10 No. 2, pp. 117-135.

Cockburn, C. (1991), In the Way of Women. Men's Resistance to Sex Equality in Organizations. MacMillan, London.

Cooney, T. (2008), "Entrepreneurs with disabilities: Profile of a forgotten minority", Irish Business Journal, Vol. 4 No. 1, pp. 119-129.

Crenshaw, K.W. (1991), "Mapping the margins: Intersectionality, identity politics, and violence against women of color", Stanford Law Review, Vol. 43 No. 6, pp. 1241-1299.

Crow, L. (1996), "Including all of our lives: Renewing the social model of disability", in Morris, J. (Ed.), Encounters with Strangers: Feminism and Disability, Women's Press, London, pp. 206-222.

Dale, K. (2005), "Building a social materiality: Spatial and embodied politics in organizational control”, Organization, Vol. 12 No. 5, pp. 649-678.

de Beauvior, S. (1972), The Second Sex, Harmondsworth, Penguin Publishing.

De Bruin, A., Brush, C.G. and Welter, F. (2007), "Advancing a framework for coherent research on women's entrepreneurship", Entrepreneurship Theory and Practice, Vol. 31 No. 3, pp. 323-339.

De Klerk, T. (2008), "Funding for self-employment of people with disabilities. Grants, loans, revolving funds or linkage with microfinance programmes", Leprosy Review, Vol. 79 No. 1, pp. $92-$ 109.

Díaz García, M-C. and Welter, F. (2011), "Gender identities and practices: Interpreting women entrepreneurs' narratives”, International Small Business Journal, Vol. 31 No. 4, pp. 384-404.

DTI, (2003), Strategic Framework for Women's Enterprise, Department for Trade and Industry: London.

Eddleston, K.A. and Powell, G. (2012), "Nurturing entrepreneurs' work-family balance: A gendered perspective”, Entrepreneurship Theory and Practice, Vol. 36 No. 3, pp. 513-541.

Essers, C. and Benschop, Y. (2009), "Muslim businesswomen doing boundary work: The negotiation of islam, gender and ethnicity within entrepreneurial contexts", Human Relations, Vol. 62 No. 3, pp. 403-423.

Fawcett, B. (2000), Feminist Perspectives on Disability, Prentice Hall, London.

Fayolle, A., Yousafzai, S., Saeed, S., Henry, C. and Lindgreen, A. (2016), "Special issue on: Contextual embeddedness of women's entrepreneurship: Taking stock and looking ahead", Entrepreneurship \& Regional Development, Vol. 27 No. 9-10, pp. 670-674.

Fleming, P. (2007), "Sexuality, power and resistance in the workplace", Organization Studies, Vol. 28 No. 2, pp. 239-256 
Forbes, G., Collinsworth, L, Jobe, R., Braun, K. and Wise, L. (2007), "Sexism, hostility toward women, and endorsement of beauty ideals and practices: Are beauty ideals associated with oppressive beliefs?”, Sex Roles, Vol. 56 No. 5-6, pp. 265-273.

Foster, D. (2007), "Legal obligation or personal lottery?: Employee experiences of disability and the negotiation of adjustments in the public sector workplace", Work, Employment and Society, Vol. 21 No. 1, pp. 67-84.

French, S. (1993), "Disability, impairment or something in between?", in Swain, J., Finklestein, V. and Oliver, M. (Eds.), Disabling Barriers - Enabling Environment, Sage, London, pp. 17-25.

Garland-Thomson, R. (2002), "Integrating disability, transforming feminist theory", NWSA, Vol. 14, No. 3, pp.1-32.

Gerodetti, N. and McNaught-Davis, M. (2017), "Feminisation of success or successful femininities? Disentangling 'new femininities' under neoliberal conditions", European Journal of Women's Studies, Vol. 24 No. 4, pp. 351-365.

Gherardi, S. and Rodeschini, G. (2016), "Caring as a collective knowledgeable doing: About concern and being concerned", Management Learning, Vol. 47, No. 3, pp. 266-284.

Godwyn. M. and Stoddard, D. (2011), Minority Women Entrepreneurs: How Outsider Status Can Lead to Better Business Practices, Greenleaf Publishing, California.

Goodley, D. (2001), "Learning difficulties, the social model of disability and impairment: Challenging epistemologies", Disability and Society, Vol. 16 No. 2, pp. 207-231.

Goodley, D. (2010), Disability Studies: An Interdisciplinary Introduction, Sage, London.

Goss, F. and Goss, D. (1998), "The Disability Discrimination Act and SMEs: The future of the threshold," Journal of Small Business and Enterprise Development, Vol. 5 No. 3, pp. 270-280.

Gray, C. (2009), "Narratives of disability and the movement from deficiency to difference", Cultural Sociology, Vol. 3 No. 2, pp. 317-332.

Hall, K. (2001), "Reimagining disability and gender through feminist disability studies: An introduction", in Hall, K. (Ed.), Feminist Disability Studies, Indiana University Press, Indiana, pp.110.

Hamilton, E. (2013), "The Discourse of Entrepreneurial Masculinities (and Femininities)," Entrepreneurship and Regional Development, Vol. 25 No. 1-2, pp. 90-99.

Harding, R. (2007) State of Women's Enterprise in the UK, Prowess, Norwich.

Harlan, S. L. and Robert, P.M. (1998), "The Social construction of disability in organizations: Why employers resist reasonable accommodation", Work and Occupations, Vol. 25 No.4, pp. 397-435.

Healy, G., Bradley, H. and Forson, C. (2011), "Intersectional sensibilities in analysing inequality regimes in public sector organizations", Gender, Work \& Organization, Vol. 18 No. 5, pp. 467-487.

Hearn, G. and Parkin, W. (2001), Gender, Sexuality and Violence in Organizations: The Unspoken Forces of Organization Violations, Sage, London. 
Hearn, J., and Parkin, W. (1987/1995), 'Sex' at 'Work': The Power and Paradox of Organisation Sexuality, Wheatsheaf, Brighton.

Hearn J., Sheppard, D., Tancred-Sheriff, P. and Burrell, G. (Eds.), (1989), The Sexuality of Organization, Sage, London.

Holvino, E. (2010), "Intersections: The simultaneity of race, gender and class in organization studies", Gender, Work \& Organization, Vol. 17 No. 3, pp. 248-277.

Hughes, B. (2007), "Being disabled: Towards a critical social ontology for disability studies", Disability and Society, Vol. 22 No. 7, pp. 673-684.

Hughes, K.D., Jennings, J.E., Brush, C., Carter, S. and Welter, F. (2012), "Extending women's entrepreneurship research in new directions", Entrepreneurship Theory and Practice, Vol. 36 No. 3, pp. $429-442$.

Ipsen. C., Arnold, N. and Colling, K. (2005), "Self-employment for people with disabilities Enhancing services through interagency linkages", Journal of Disability Policy Studies, Vol. 15 No. 4, pp. 231-239.

Jolly, D. (2000), "A critical evaluation of the contradictions for disabled workers arising from the emergence of the flexible labour market in Britain", Disability \& Society, Vol. 15 No. 5, pp. 795-810.

Kelan, E.K. (2008), "The discursive construction of gender in contemporary management literature", Journal of Business Ethics, Vol. 81 No. 2, pp. 427-445.

Kitchin, R., Shirlow, P. and Shuttleworth, I. (1998), "On the Margins: Disabled people's experience of employment in Donegal, West Ireland”, Disability and Society, Vol. 13 No. 5, pp. 785-806.

Kitching, J. (2014) Entrepreneurship and Self-Employment by People With Disabilities. OECD

Kittay, E.F., Jennings, B. and Wasunna, A. (2005), "Dependency, difference and the global ethic of longterm care", The Journal of Political Philosophy, Vol. 13 No. 4, pp. 443-469.

Kumra, S. (2010), "The social construction of merit in a professional service firm: What is in and who is out?", British Academy of Management Conference: Management Research in a Changing Climate, The University of Sheffield, Sheffield, 14-16 September, Brunel University: Uxbridge, UK.

Lee-Gosselin, H. and Grise, J. (1990), "Are women owner-managers challenging our definitions of entrepreneurship? An in-depth survey”, Journal of Business Ethics, Vol. 9 No. 4-5, pp. 423-433.

Lewis, P. (2004), "Using conflict to highlight the gendered nature of entrepreneurship: The case of the career woman entrepreneur." Paper presented at British Academy of Management, St Andrews, September, Canterbury, Kent Business School.

Lewis, P. (2006), "The quest for invisibility: Female entrepreneurs and the masculine norm of entrepreneurship", Gender, Work and Organization, Vol. 13 No. 5, pp. 453-469.

Lewis, P. (2009), "The search for authentic enterprise identity; difference and professionalism among women business owners." Paper presented at British Academy of Management, Brighton Centre, Brighton, 15-17 $7^{\text {th }}$ September, Canterbury, Kent Business School.

Liddiard, K. (2011), “(S)exploring Disability: Intimacies, Sexualities and Disabilities”, PhD dissertation, University of Warwick. 
Liddiard, K. (2014) "The work of disabled identities in intimate relationships", Disability \& Society, 29(4), pp. 115-128.

McCall, L. (2005), “The complexity of intersectionality." Signs: Journal of Women in Culture and Society, Vol. 30 No. 3, pp. 1771-1880.

McRobbie, A. (2015), "Notes on the perfect”, Australian Feminist Studies, Vol. 30 No. 83, pp. 3-20.

Marlow, S. (2006), "Enterprising futures of dead-end jobs? Women, self-employment and social exclusion", International Journal of Manpower, Vol. 27 No. 6, pp. 588-600.

Marlow, S., Henry, C. and Carter, S. (2009), "Exploring the impact of gender upon women's business ownership", International Small Business Journal, Vol. 27 No. 2, pp. 139-147.

Marlow, S. and Patton, D. (2005), "All credit to men? Entrepreneurship, finance and gender", Entrepreneurship: Theory and Practice, Vol. 29 No. 6, pp. 717-735.

Messerschmidt, J.W. (2009), “'Doing gender': The impact of a salient sociological concept”, Gender and Society, Vol. 23 No. 1, pp. 85-88.

Mirchandani, K. (1999) "Feminist insight on gendered work: New directions in research on women and entrepreneurship", Gender, Work \& Organization, Vol. 64 No. 4, pp. 224-35.

Mol, A. (2008), The Logic of Care: Health and the Problem of Patient Choice. Routledge, New York.

Morris, J. (1991), Pride Against Prejudice: Transforming Attitudes to Disability, The Women's Press: London.

Morris, J. (1993a), “Feminism and disability”, Feminist Review Vol. 43 No. 1, pp. 57-70.

Morris, J. (1993b), “Gender and disability”, in Swain, J., Finklestein, V., French, S. and Oliver, M. (Eds.), Disabling Barriers-Enabling Environments, Sage, London, pp. 85-92.

Morris, J. (1993c), Independent Lives? Community Care and Disabled People, Macmillan, London.

Morris, J. (1996), Encounters with Strangers: Feminism and Disability, The Women's Press, London.

Mumby, D.K. and Clair, R.P. (1997), "Organizational discourse”, in Van Dijk, T.A. (Ed.), Discourse as Social Interaction, Sage, London, pp. 181-205.

Niekerk, L.V., Lorenzo, T. and Mdlokolo, P. (2006), "Understanding partnerships in developing disabled entrepreneurs through participatory action research", Disability and Rehabilitation, Vol. 28 No. 5, pp. 323-331.

Ogbor, J. O. (2000), "Mythicizing and reification in entrepreneurial discourse: ideology critique of entrepreneurial studies", Journal of Management Studies, Vol. 37 No. 5, pp. 605-635.

Oliver, M. (1983), Social Work with Disabled People, Macmillan, Basingstoke.

Oliver, M. (1990), The politics of Disablement, Macmillan, Basingstoke.

Oliver, M. (1996), Understanding Disability: From Theory to Practice, Macmillan, Basingstoke. 
Oliver, M. (2009). Understanding Disability: From Theory to Practice, 2nd ed., Palgrave MacMillan, Basingstoke.

Overboe, J. (1999), "Difference in itself: Validating disabled people's lived experience", Body \& Society, Vol. 5 No. 4, pp. 17-29.

Pagán, R. (2009), “Self-Employment among people with disabilities: Evidence from Europe', Disability \& Society, Vol. 24 No. 2, pp. 217-229.

Pavey, B. (2006), "Human capital, social capital, entrepreneurship and disability: An examination of some current educational trends in the UK", Disability \& Society, Vol. 21 No. 3, pp. 217-229.

Price, J. and Shildrick, M. (2002), "Bodies together: Touch, ethics and disability", in Corker, M. and Shakespeare, T. (Eds.), Disability/Postmodernity: Embodying Disability Theory, Continuum, London, pp. 62-75.

Rohrer, Judy (2005). Toward a full-inclusion feminism: A feminist deployment of disability analysis. Feminist Studies, Vol. 31 No.1, pp.34-63.

Roomi, M., Harrison, P. and Beaumont-Kerridge, J. (2009), "Women-owned small and medium enterprises in England: Analysis of factors influencing the growth process", Journal of Small Business and Enterprise Development, Vol. 16 No. 2, pp. 270-288.

Rouse, J. and Jayawarna, D. (2006), "The financing of disadvantaged entrepreneurs: Are enterprise programmes overcoming the finance gap?", International Journal of Entrepreneurial Behaviour and Research, Vol. 12 No. 6, pp. 388-400.

Shakespeare, T., Gillespie-Sells, K. and Davies, D. (1996) The Sexual Politics of Disability: Untold Desires, Cassell, London.

Shildrick, M. (2009), Dangerous Discourses of Disability, Subjectivity and Sexuality, Palgrave, London

Shields, S. A. (2008), “Gender: An intersectionality perspective”, Sex Roles, Vol. 59, pp.301-311.

Simpson, R. and Lewis, P. (2005), "An investigation of silence and a scrutiny of transparency: ReExamining gender in organization literature through the concepts of voice and visibility", Human Relations, Vol. 58 No. 10, pp. 1253-1275.

Sunderland, J. (2004), Gendered Discourses, Palgrave Macmillan, Basingstoke.

Swail, J. and Marlow, S. (2018), "Embrace the masculine; attentuate the feminine - gender, identity work and entrepreneurial legitimation in the nascent context", Entrepreneurship \& Regional Development: An International Journal, Vol. 30, No. 1-2, pp. 256-282.

Thomas, C. (1999), Female Forms: Experiencing and Understanding Disability, Open University Press, Buckingham.

Thomas, C. (2001), "Feminism and disability: The theoretical and political significance of the personal and the experiential", in Barton, L. (Ed.), Disability, Politics and the Struggle for Change, David Fulton, London, pp.48-58 11. 
Thomas, C. (2006), "Disability and gender: Reflections on theory and research", Scandinavian Journal of Disability Research, Vol. 8 No. 2-3, pp. 177-185.

Thomas, C. (2007), Sociologies of Disability and Illness. Contested Ideas in Disability Studies and Medical Sociology, Palgrave Macmillan, Basingstoke.

Thomas, R. and Linstead, A. (2002), “'Losing the plot?' Middle managers and identity", Organization, Vol. 9 No. 1, pp. 71-93.

Tremain, S. (2005), Foucault and the Government of Disability, The University of Michigan Press, Ann Arbor.

Weeks, J. (1986), Sexuality, Routledge, London.

Welter, F. (2011), "Contextualizing entrepreneurship - Conceptual challenges and ways forward", Entrepreneurship Theory and Practice, Vol. 35 No. 1, pp. 165-184.

Welter, F. (2012), "Entrepreneurship in context”, International Small Business Journal, Vol. 30 No. 6, pp. 728-730.

West, C. and Zimmerman, D.H. (2009), “Accounting for doing gender”, Gender and Society, Vol. 23 No. 1, pp. 112-122.

Williams, B., Copestake, P., Eversley, J. and Stafford, B. (2011), "Experiences and Expectations of Disabled People - Executive Summary. A Research Report for the Office for Disability Issues", Office for Public Management, and University of Nottingham: London.

Zanoni, P. (2011), "Diversity in the lean automobile factory: Doing class through gender, disability and age", Organization, Vol. 18 No. 1 pp. 105-127.

\footnotetext{
${ }^{\mathrm{i}}$ We recognize that within the US and Canada language use tends to reflect an understanding of disability within a minority politics perspective (and use of the term people with disabilities). In the UK disability scholars are more likely to draw upon social model or social interpretation language which understands disability as an issue of social exclusion and conceptualizes disability as a consequence of social responses to people living with impairment. The literature upon which this article draws is primarily located within the UK social interpretation perspective and therefore is orientated to the terms disabled people and disabled women (Goodley, 2010; Author and Colleague, 2012)
}

\section{Author Comments}

The authors wish to thank the special issue editors and the reviewers for their developmental and supportive comments and suggestions throughout the review process. 